\title{
The determinants of increasing equity market comovement: economic or financial integration?
}

\author{
Lieven Baele $\cdot$ Pilar Soriano
}

Published online: 25 May 2010

(C) The Author(s) 2010. This article is published with open access at Springerlink.com

\begin{abstract}
This paper investigates to what extent the substantial increase in exposures of local European equity market returns to global shocks is mainly due to a convergence in cash flows ("economic integration"), to a convergence in discount rates ("financial integration"), or to both. We find that this increased exposure is nearly entirely due to increasing discount-rate betas. This finding is robust to alternative ways of calculating discount-rate and cash-flow shocks.
\end{abstract}

Keywords Economic integration - Financial integration · Cash-flow news · Discount-rate news

JEL Classification $\mathrm{G} 11 \cdot \mathrm{G} 12 \cdot \mathrm{G} 15 \cdot \mathrm{C} 32 \cdot \mathrm{F} 37$

\section{Introduction}

There is increasing consensus that globalization and integration lead to substantially higher equity market betas and correlations. Apart from in emerging markets, the evidence is particularly strong in Europe, a region where integration has made considerable progress over the last 20 years. ${ }^{1}$

\footnotetext{
1 See e.g. Longin and Solnik (1995), Bekaert and Harvey (2000), Baele et al. (2004), Baele (2005), Baele and Inghelbrecht (2009) and Bekaert et al. (2009).

L. Baele $(\square)$

CentER, Netspar, and Tilburg University, PO Box 90153, 5000 LE Tilburg, The Netherlands e-mail: Lieven.Baele@uvt.nl

P. Soriano

Departament d'Economia Financera i Actuarial, Universitat de Valencia, Avda. Tarongers s/n, 46022 Valencia, Spain

e-mail: Pilar.Soriano-Felipe@uv.es
} 
A yet unresolved question is what type of integration is behind these increases in market betas and correlations. In fact, cross-country equity market correlations could increase because of economic integration through a convergence in crosscountry cash flows, because of financial integration through a convergence in crosscountry discount rates, or through both. The aim of this paper is to quantify the relative importance of economic and financial integration in explaining timevarying equity market betas and correlations.

Distinguishing between both effects is important for a number of reasons. First, cross-market interdependences and correlations have frequently been used as indirect measures of financial integration. By separately correcting for economic integration, we should obtain a cleaner measure of financial integration. Second, differences in the degree of and time variation in, respectively, economic and financial integration may explain why equity correlations vary substantially across countries and over time. For instance, is one market more correlated with the world equity market because its cash flows are more similar, because it is relatively better financially integrated, or a combination of both? Last but not least, by identifying the different sources of market comovement in 'normal' times, our analysis should also provide for a better identification of the various channels through which contagion may occur.

To empirically study the relative importance of economic and financial integration, we focus on a large sample of 21 equity markets from both Western and Eastern Europe. We do this for a number of reasons. First, over the last decades, Europe has gone through an extraordinary period of increasing integration, including the introduction of the euro in 1999 and the accession of 10 new members to the European Union in 2004. Second, the comparison of countries in an economically homogeneous region with those that opted to stay out of the economic (and monetary) union offers an ideal test for the main hypothesis in this paper. Third, this analysis may hold important lessons for the recently emerged equity markets in Central and Eastern European countries which have just embarked or are about to embark on the integration process.

In our analysis, we jointly determine to what extent global market betas have increased over time, and to what extent this increase is due to a convergence in cash-flow expectations (related to further economic integration) or in discount rates (resulting from increasing financial integration). As in the previous literature, we use the US market - still by far the dominant equity market in the world - as a proxy for the global market portfolio. We use the VAR methodology developed in Campbell and Shiller (1988a) and Campbell (1991) to decompose the return on the US market into a component due to revisions in future cash flows and a part due to news about future discount rates. Campbell and Mei (1993) decomposed the betas of industry and size portfolios into components attributable to news about future cash flows, real interest rates, and excess returns. In a recent paper, Campbell and Vuolteenaho (2004) showed that the size and value anomalies in stock returns can be explained by allowing stocks to have a different exposure to cash-flow and discount-rate news.

To our knowledge, this paper is the first to decompose country betas with respect to a common global market shock (here proxied by the US market) in a discount-rate 
and cash-flow beta. This allows us to quantify whether the increase in the total market beta is mainly due to an increase in the cash-flow beta (economic integration) or in the discount-rate beta (financial integration). We find that this increase is nearly fully the consequence of an increase in the discount-rate beta.

This paper is most closely related to the work of Ammer and Mei (1996), Phylaktis and Ravazzolo (2002), and Engsted and Tanggaard (2004). Ammer and Mei (1996) decompose the returns on the equity markets of 15 industrialized countries in a cash-flow and discount-rate component over the period 1974-1990. Consequently, they interpret the cross-country correlations between discount and cash-flow news as measures of, respectively, financial and economic integration. Phylaktis and Ravazzolo (2002) perform a similar analysis on a set of Pacific-Basin equity markets. Engsted and Tanggaard (2004) is also similar in spirit to Ammer and Mei (1996). They find that news about future excess returns is the main determinant of stock market volatility in both the US and the UK, and that this news component is highly cross-country correlated.

The main difference between these studies and ours is that we look at exposures to cash-flow and discount-rate shocks as measures of economic and financial integration instead of correlations in, respectively, cash-flow and discount-rate shocks. The main advantage of looking at exposures rather than at correlations is that the former are not vulnerable to the conditioning bias of Forbes and Rigobon (2002). More specifically, rising cross-country correlations may be purely the result of an increase in the volatility of cash-flow/discount-rate shocks rather than of increasing integration. For instance, the high correlations observed at the end of the 1990s/early 2000s are most likely more the result of high common factor volatility following the build-up and burst of the technology bubble rather than of a sudden increase in integration. An additional difference is that we consider a broad range of both Western and Eastern European countries, and that our sample period covers a wider range of data including the early 2000s, where the process of further European integration was still taking place.

The remainder of this paper is organized as follows. Section 2 describes, first, how global market shocks can be decomposed in news about future cash flows and discount rates and, second, how to measure cash-flow and discount-rate exposures. Section 3 reports the empirical results and some robustness checks. Finally, Sect. 4 concludes.

\section{Decomposing global risk into cash-flow and discount-rate news}

\subsection{Cash-flow and discount-rate news}

As in Campbell and Shiller (1988a) and Campbell (1991), we use the log-linear approximate decomposition of unexpected returns: ${ }^{2}$

\footnotetext{
${ }^{2}$ We considered including exchange rates in this decomposition, but decided not to do so. The main reason is that exchange rates are virtually unpredictable. Consequently, shocks to instruments have no long-lasting effects on future exchange rates, and hence on returns. There could be a contemporaneous but relatively small effect though.
} 


$$
\begin{gathered}
r_{t+1}-E_{t} r_{t+1}=\left(E_{t+1}-E_{t}\right) \sum_{j=0}^{\infty} \rho^{j} \Delta d_{t+1+j}-\left(E_{t+1}-E_{t}\right) \sum_{j=1}^{\infty} \rho^{j} r_{t+1+j} \\
=N_{C F, t+1}-N_{D R, t+1}
\end{gathered}
$$

where $r_{t+1}$ is a log stock return, $d_{t+1}$ is the log dividend, $\Delta$ denotes a one-period change, $E_{t}$ denotes a rational expectation at time $t$, and $\rho$ is a discount-rate coefficient. ${ }^{3} N_{C F, t+1}$ denotes news about future cash flows at time $t+1$. Similarly, $N_{D R, t+1}$ represents news about future discount rates. Notice that Eq. 1 can be considered as a consistent model of expectations, since a positive (negative) unexpected return today must be only associated with an upward (downward) revision in expectations about future cash flows, a downward (upward) revision in expectations about future returns, or a combination of both. It should also be noted that Eqs. 1 and 2 will only hold in the absence of bubbles.

To implement this decomposition, we follow Campbell (1991) and estimate the cash-flow news and discount-rate news series using a vector autoregressive (VAR) model. This VAR methodology first estimates the terms $E_{t} r_{t+1}$ and $\left(E_{t+1}-E_{t}\right)$ $\sum_{j=1}^{\infty} \rho^{j} r_{t+1+j}$ and then uses $r_{t+1}$ and Eq. 1 to back out the cash-flow news. As pointed out by Campbell and Vuolteenaho (2004), this practice has an important advantage - one does not necessarily have to understand the short-run dynamics of dividends. Understanding the dynamics of expected returns is enough, as cash-flow and discount-rate news can be obtained through the linear functions described in Eqs. 4 and 5.

We assume that the data are generated by a first-order VAR model

$$
\mathbf{z}_{t+1}=\mathbf{a}+\Gamma \mathbf{z}_{t}+\mathbf{u}_{t+1}
$$

where $\mathbf{z}_{t+1}$ is a $m$-by-1 state vector with $r_{t+1}$ as its first element, $\mathbf{a}$ and $\boldsymbol{\Gamma}$ are an $m$-by-1 vector and $m$-by- $m$ matrix of constant parameters, and $\mathbf{u}_{t+1}$ an i.i.d. $m$-by-1 vector of shocks. Of course, this formulation also allows for higher-order VAR models via a simple redefinition of the state vector to include lagged values.

Provided that the process in Eq. 3 generates the data, $t+1$ cash-flow and discount-rate news are linear functions of the $t+1$ shock vector:

$$
\begin{gathered}
N_{C F, t+1}=\left(\mathbf{e} 1^{\prime}+\mathbf{e} 1^{\prime} \lambda\right) \mathbf{u}_{t+1} \\
N_{D R, t+1}=\mathbf{e} 1^{\prime} \lambda \mathbf{u}_{t+1}
\end{gathered}
$$

The VAR shocks are mapped to news by $\lambda$, defined as $\lambda=\rho \boldsymbol{\Gamma}(\mathbf{I}-\rho \boldsymbol{\Gamma})^{-1}$. The long-run significance of each individual VAR shock to discount-rate expectations is captured by $\mathbf{e} \mathbf{1}^{\prime} \lambda$, where $\mathbf{e} \mathbf{1}$ is a vector whose first element is equal to one and zero otherwise. The greater the absolute value of a variable's coefficient in the return prediction equation (the top row of $\boldsymbol{\Gamma}$ ), the greater the weight the variable receives in the discount-rate-news formula. More persistent variables should also receive more weight, which is captured by the term $(\mathbf{I}-\rho \mathbf{\Gamma})^{-1}$.

\footnotetext{
3 As in Campbell and Vuolteenaho (2004), we set $\rho=0.95^{1 / 12}$. Recall that it can be related to either the average dividend yield or the average consumption wealth ratio.
} 


\subsection{Measuring global cash-flow and discount-rate exposures}

We showed in the previous section how unexpected returns can be decomposed into two news components. An interesting question is whether increasing exposure to global shocks is a result of increasing exposure to cash-flow news or increasing exposure to discount-rate news. Moreover, different countries may have different betas or exposures to these two components of the global market. Following Campbell and Vuolteenaho (2004), using the excess returns $\left(r_{i, t}^{e}\right)$ of a particular country $i$, we define the cash-flow beta as

$$
\beta_{i, C F} \equiv \frac{\operatorname{Cov}\left(r_{i, t}^{e}, N_{C F, t}\right)}{\operatorname{Var}\left(r_{U S, t}^{e}-E_{t-1} r_{U S, t}^{e}\right)}
$$

and the discount-rate beta as

$$
\beta_{i, D R} \equiv \frac{\operatorname{Cov}\left(r_{i, t}^{e},-N_{D R, t}\right)}{\operatorname{Var}\left(r_{U S, t}^{e}-E_{t-1} r_{U S, t}^{e}\right)}
$$

Therefore, the global market beta can be decomposed into components in a simple way:

$$
\beta_{i, U S}=\beta_{i, C F}+\beta_{i, D R}
$$

We define betas by using unconditional variances and covariances. However, we will report betas using the whole sample period and also betas using different subperiods, in order to get an idea of their evolution in time. An increase in economic and financial integration would be consistent with an increase in, respectively, $\beta_{i, C F}$ and $\beta_{i, D R}$. This framework enables us to analyze the variation across countries and across time in the two components of the market beta.

\section{Empirical results}

\subsection{US cash-flow and discount-rate news}

Section 2 explained how unexpected stock returns can be decomposed into a component due to revisions in expectations of future cash flows and a part due to revisions in expectations of future discount rates within a straightforward first-order VAR framework. To operationalize this VAR approach, we need to specify the variables to be included into the state vector $\left(z_{t+1}\right)$. Following Campbell and Vuolteenaho (2004), we choose the following four state variables: the excess market return (measured as the log excess return on the CRSP value-weighted index over Treasury bills), the yield spread between long-term and short-term bonds (measured as the yield difference between 10-year constant-maturity taxable bonds and threemonth taxable notes, in annualized percentage points), the market's smoothed priceearnings ratio (measured as the log ratio of the S\&P500 price index to a 10-year moving average of S\&P500 earnings), and the small-stock value spread (measured as the difference between the log book-to-market ratios of small value and small 
Table 1 Descriptive statistics of the VAR state variables

\begin{tabular}{lcccccc}
\hline Variable & Mean & Median & \multicolumn{1}{l}{ Stdev. } & \multicolumn{1}{l}{ Min } & Max & Autocorr. \\
\hline$r_{M, t}^{e}$ & 0.0043 & 0.0093 & 0.0548 & -0.3442 & 0.3222 & 0.1022 \\
$T Y_{t}$ & 0.7059 & 0.5700 & 0.7373 & -1.3500 & 3.1400 & 0.9268 \\
$P E_{t}$ & 2.8878 & 2.8868 & 0.3742 & 1.5006 & 3.8906 & 0.9914 \\
$V S_{t}$ & 1.6511 & 1.5250 & 0.3668 & 1.1922 & 2.7134 & 0.9909 \\
\hline Correlations & & $r_{M, t}^{e}$ & $T Y_{t}$ & & $P E_{t}$ & $V S_{t}$ \\
\hline$r_{M, t}^{e}$ & 1 & & & \\
$T Y_{t}$ & & 0.0580 & 1 & & \\
$P E_{t}$ & & -0.0064 & -0.1134 & & \\
$V S_{t}$ & -0.0314 & -0.3679 & -0.3154 & 1 \\
\hline
\end{tabular}

The table shows the descriptive statistics of the VAR state variables estimated from the full sample period 1928:12-2005:12, 925 monthly data points. $r_{M, t}^{e}$ is the excess log return on the CRSP value-weight index. $T Y_{t}$ is the term yield spread in percentage points, measured as the yield difference between 10-year constant-maturity taxable bonds and short-term taxable notes. $P E_{t}$ is the log ratio of S\&P 500's price to S\&P 500's 10-year moving average of earnings. $V S_{t}$ is the small-stock value spread, the difference in the $\log$ book-to-market ratios of small value and small growth stocks. "Stdev." denotes standard deviation and "Autocorr." the first-order autocorrelation of the series

growth stocks). Our monthly data covers the period January 1929-December 2005. For January 1929-December 2001, data is taken from Tuomo Vuolteenaho's Web site. For the rest of the sample period, we obtain the variables following Campbell and Vuolteenaho (2004). Thus, excess market return data is from CRSP, yield spread data is from FRED (Federal Reserve Economic Data), the price-earnings ratio is from Shiller (2000), and the small-stock value spread is constructed from the data made available by Professor Kenneth French on his Web site. ${ }^{4}$ Summary statistics are reported in Table 1.

The first two predictor variables have become standard instruments in the return predictability literature. The term spread variable is consistently shown to be a leading indicator of real economic activity, and hence stock prices. Estrella and Hardouvelis (1991) and Estrella and Mishkin (1998) show that for the United States the yield spread significantly outperforms other financial and macroeconomic indicators in forecasting recessions. Bernard and Gerlach (1998), Estrella and Mishkin (1997), and Ahrens (2002) present similar results for other countries. In addition, several papers (e.g., Campbell 1987; Fama and French 1989; Campbell and Yogo 2006) have found a positive relation between the term structure and equity returns. Second, high price-earnings ratios are associated with low long-run expected returns, at least to the extent that earnings growth is constant. For instance, Fama and French (1988) and Campbell and Shiller (1988b) find that price-dividend and price-earnings ratios predict future real equity returns, and, more recently, Campbell and Vuolteenaho (2004) and Hecht and Vuolteenaho (2006) also provide evidence on how log price-earnings ratios negatively predict returns. The third, less standard, variable is the small-stock value spread. Campbell and Vuolteenaho

\footnotetext{
${ }^{4}$ http://mba.tuck.dartmouth.edu/pages/faculty/ken.french/data_library.html.
} 
(2004) offer a number of reasons for why this variable may be linked to expected returns. First, small growth stocks may generate cash flows in the more distant future and therefore their prices are more sensitive to changes in discount rates. Second, small growth companies may be particularly dependent on external financing and thus are sensitive to equity market and broader financial conditions. Finally, they argue that episodes of irrational investor optimism are likely to have a particularly powerful effect on small growth shocks.

Table 2 reports the parameter estimates for the VAR model. Row 1 to 4 correspond to, respectively, the equations for the excess equity market returns, the term spread, the price-earnings ratio, and the small-stock value spread. The first five columns report coefficients on the five explanatory variables: a constant, and lags of the excess market return, term yield spread, price-earnings ratio, and small-stock value spread. OLS standard errors and Bootstrap standard errors are also reported. The final two columns report the $R^{2}$ and $F$-statistics for each regression. The first row of Table 2 shows that all predictor variables have a statistically significant relation with the excess market returns. The coefficient on the lagged market return amounts to 0.0949 , consistent with a modest degree of momentum. The term yield spread positively predicts the market return. The term spread accounts for a term or maturity risk premium, therefore leading to that positive relation (see Fama and French 1989). The smoothed price-earnings ratio is-consistent with previous

Table 2 VAR parameter estimates

\begin{tabular}{cccccccc}
\hline & Constant & $r_{M, t}^{e}$ & $T Y_{t}$ & $P E_{t}$ & $V S_{t}$ & $R^{2}(\%)$ & $F$ \\
\hline$r_{M, t+1}^{e}$ & 0.0656 & 0.0949 & 0.0051 & -0.0156 & -0.0122 & 2.52 & 5.95 \\
& {$[0.0191]$} & {$[0.0326]$} & {$[0.0026]$} & {$[0.0050]$} & {$[0.0054]$} & & \\
& $(0.0113)$ & $(0.0236)$ & $(0.0029)$ & $(0.0144)$ & $(0.0012)$ & & \\
$T Y_{t+1}$ & -0.0372 & 0.0144 & 0.9138 & -0.0006 & 0.0717 & 86.38 & 1457.21 \\
& {$[0.0959]$} & {$[0.1639]$} & {$[0.0131]$} & {$[0.0003]$} & {$[0.0275]$} & & \\
& $(0.0663)$ & $(0.1210)$ & $(0.0150)$ & $(0.0742)$ & $(0.0076)$ & & \\
$P E_{t+1}$ & 0.0237 & 0.5164 & 0.0010 & 0.9923 & -0.0028 & 99.06 & 24258.38 \\
& {$[0.0128]$} & {$[0.0218]$} & {$[0.0017]$} & {$[0.0033]$} & {$[0.0036]$} & & \\
& $(0.0079)$ & $(0.0156)$ & $(0.0019)$ & $(0.0095)$ & $(0.0009)$ & & \\
$V S_{t+1}$ & 0.0166 & -0.0062 & -0.0006 & -0.0009 & 0.9916 & 98.27 & 13126.80 \\
& {$[0.0170]$} & {$[0.0290]$} & {$[0.0023]$} & {$[0.0044]$} & {$[0.0048]$} & & \\
& $(0.0103)$ & $(0.0211)$ & $(0.0026)$ & $(0.0127)$ & $(0.0011)$ & & \\
\hline
\end{tabular}

The table shows the OLS parameter estimates for a first-order VAR model including a constant, the log excess market return $\left(r_{M, t}^{e}\right)$, term yield spread $\left(T Y_{t}\right)$, price-earnings ratio $\left(P E_{t}\right)$, and small-stock value spread $\left(V S_{t}\right)$. Each set of three rows corresponds to a different dependent variable. The first five columns report coefficients on the five explanatory variables, and the remaining columns show $R^{2}$ and $F$-statistics. The $F$-statistic tests joint significance of all regressors. OLS standard errors are in square brackets and bootstrap standard errors are in parentheses. Bootstrap standard errors are computed from 2,500 simulated realizations. We select 2,500 independent bootstrap samples, each consisting of a block of consecutive observations drawn with replacement from our data set. We then evaluate the bootstrap replication corresponding to each bootstrap sample and estimate the standard error by the sample standard deviation of the 2,500 replications. Sample period for the dependent variables is 1928:12-2005:12, 925 monthly data points 
findings - negatively related to expected returns. Finally, the small-stock value spread negatively predicts stock returns, consistent with findings in Eleswarapu and Reinganum (2004) and Brennan et al. (2004). The $R^{2}$ is reasonable for a monthly expected return model. Rows 2 till 4 summarize the dynamics of the explanatory variables. The term spread has a high degree of autocorrelation (AR(1) coefficient of 0.9138). Interestingly, also the small-stock value spread has some predictive power for the term spread. Finally, the price-earnings ratio and the small-stock value spread ratio are both highly persistent, with roots (very) close to unity.

Table 3 reports summary statistics of the cash-flow and discount-rate news variables as implied by the VAR estimates. A first observation is that discount-rate news is double as volatile as cash-flow news (a monthly volatility of, respectively, 4.84 and 2.62\%). This confirms the finding of Campbell (1991) that discount-rate news is the dominant component of the market return. The table also shows that the two components of return are almost uncorrelated with one another. Following Campbell and Vuolteenaho (2004), Table 3 also reports the correlations of each state variable innovation with the estimated news terms, and the coefficients $\left(\mathbf{e} \mathbf{1}^{\prime}+\mathbf{e} \mathbf{1}^{\prime} \lambda\right)$ and $\mathbf{e} \mathbf{1}^{\prime} \lambda$ that map innovations to cash-flow and discount-rate news. Innovations to returns are highly negatively correlated with discount-rate news, reflecting the mean reversion in stock prices that is implied by our VAR system. Market-return innovations are weakly positively correlated with cash-flow news, indicating that some part of a market rise is typically justified by underlying improvements in expected future cash flows. Innovations to the price-earnings ratio, however, are weakly negatively correlated with cash-flow news, suggesting that price increases relative to earnings are not usually justified by improvements in future earnings growth.

\subsection{Cash-flow and discount-rate betas}

In this section, we investigate whether the 21 local European equity returns considered have become more exposed to US equity market shocks, and to what extent this increased exposure is due to a convergence in cash-flow and/or discountrate news. We use Datastream's Total Market indices as proxies for country returns. All returns are expressed in US dollars ${ }^{5}$ and include dividends. Datastream indices have as an advantage over MSCI indices that they cover a larger part of the market (up to about $80 \%$ of total market capitalization). For most countries, returns are available as from January 1973.

Table 4 reports estimates of the total, cash-flow and discount-rate beta with respect to the US market for all countries over the full period (1973-2005) and the subperiods 1973-1979, 1980-1989, 1990-1999, and 2000-2005. Figure 1 plots the average total, cash-flow and discount-rate betas over the four subperiods, while Fig. 2 compares the cash-flow and discount-rate betas across countries. Consistent with Baele (2005) and Baele and Inghelbrecht (2009), we find a substantial increase

\footnotetext{
${ }^{5}$ In unreported results, we investigate the robustness of our findings to using local instead of US dollar returns. We find that results are very similar for nearly all countries. Results are available upon request from the authors.
} 
Table 3 Cash flow and discount rate news for the market portfolio

\begin{tabular}{|c|c|c|c|c|c|}
\hline News covariance & $N_{C F}^{U S}$ & $N_{D R}^{U S}$ & News corr/std & $N_{C F}^{U S}$ & $N_{D R}^{U S}$ \\
\hline$N_{C F}^{U S}$ & $\begin{array}{c}0.0007 \\
(0.0001)\end{array}$ & $\begin{array}{c}0.0000 \\
(0.0001)\end{array}$ & $N_{C F}^{U S}$ & $\begin{array}{c}0.0262 \\
(0.0012)\end{array}$ & $\begin{array}{c}0.0359 \\
(0.0600)\end{array}$ \\
\hline$N_{D R}^{U S}$ & $\begin{array}{c}0.0000 \\
(0.0001)\end{array}$ & $\begin{array}{c}0.0023 \\
(0.0002)\end{array}$ & $N_{D R}^{U S}$ & $\begin{array}{c}0.0359 \\
(0.0600)\end{array}$ & $\begin{array}{c}0.0484 \\
(0.0019)\end{array}$ \\
\hline Shock correlations & $N_{C F}^{U S}$ & $N_{D R}^{U S}$ & Functions & $N_{C F}^{U S}$ & $N_{D R}^{U S}$ \\
\hline$r_{M, t}^{e}$ shock & $\begin{array}{c}0.4451 \\
(0.0515)\end{array}$ & $\begin{array}{r}-0.8647 \\
(0.0118)\end{array}$ & $r_{M, t}^{e}$ shock & 0.6358 & -0.3642 \\
\hline $\mathrm{TY}_{\mathrm{t}}$ shock & $\begin{array}{c}0.1138 \\
(0.0345)\end{array}$ & $\begin{array}{c}0.0540 \\
(0.0359)\end{array}$ & $T Y_{t}$ shock & 0.0284 & 0.0284 \\
\hline$P E_{t}$ shock & $\begin{array}{r}-0.0081 \\
(0.0509)\end{array}$ & $\begin{array}{r}-0.0885 \\
(0.0474)\end{array}$ & $P E_{t}$ shock & -0.8293 & -0.8293 \\
\hline$V S_{t}$ shock & $\begin{array}{r}-0.0581 \\
(0.0444)\end{array}$ & $\begin{array}{r}-0.0253 \\
(0.0436)\end{array}$ & $V S_{t}$ shock & -0.2688 & -0.2688 \\
\hline
\end{tabular}

The table shows the properties of cash-flow news $\left(N_{C F}\right)$ and discount-rate news $\left(N_{D R}\right)$ implied by the VAR model of Table 2. The upper-left section of the table shows the covariance matrix of the news terms. The upper-right section shows the correlation matrix of the news terms with standard deviations on the diagonal. The lower-left section shows the correlation of shocks to individual state variables with the news terms. The lower right section shows the functions $\left(\mathbf{e} \mathbf{1}^{\prime}+\mathbf{e} \mathbf{1}^{\prime} \lambda, \mathbf{e} \mathbf{1}^{\prime} \lambda\right)$ that map the state-variable shocks to cash-flow and discount-rate news. We define $\lambda \equiv \rho \boldsymbol{\Gamma}(\mathbf{I}-\rho \boldsymbol{\Gamma})^{-1}$, where $\boldsymbol{\Gamma}$ is the estimated VAR transition matrix from Table 2 and $\rho$ is set to 0.95 per annum. $r_{M, t}^{e}$ is the excess log return on the CRSP value-weight index, $T Y_{t}$ is the term yield spread, $P E_{t}$ is the price-earnings ratio, and $V S_{t}$ is the small-stock value spread. Bootstrap standard errors (in parentheses) are computed from 2,500 simulated realizations

in the exposure of local European equity markets to US equity market shocks. More specifically, the average US market exposure increased from about 0.48 in the second half of the 1970 s to 0.61 in the 1980 s, 0.68 in the 1990 s, and 0.88 in the period 2000-2005. Panel B and C of Table 4 and Fig. 2 clearly show that this increase is nearly entirely the result of an increase in discount-rate betas. Cash-flow betas are generally very small, statistically insignificant, and if anything, decreasing over time. We conclude from this analysis that the increased exposure of local European equity markets to the US market is largely the result of increased European financial market integration. This analysis also shows that global (regional) market exposures are a useful measure of financial market integration in a sense that the effect of further economic integration on market betas is only of second order.

\subsection{Robustness checks}

\subsubsection{Post-1952 data}

According to Chen and Zhao (2009), an interesting robustness check is to estimate cash-flow and discount-rate news using only postwar data. They suggest it is worth 
Table 4 Total, cash flow and discount rate betas

\begin{tabular}{|c|c|c|c|c|c|}
\hline & Full sample & $1970 \mathrm{~s}$ & $1980 \mathrm{~s}$ & $1990 \mathrm{~s}$ & $2000 \mathrm{~s}$ \\
\hline \multicolumn{6}{|c|}{ Panel A: Total beta with respect to US market } \\
\hline Austria & $0.24 * * *$ & 0.15 & $0.24 * *$ & $0.38 * *$ & $0.27 * *$ \\
\hline Belgium & $0.52 * * *$ & $0.49 * * *$ & $0.57 * * *$ & $0.45^{* * *}$ & $0.58 * * *$ \\
\hline Finland & $1.08 * * *$ & & & $1.03 * * *$ & $1.25 * * *$ \\
\hline France & $0.73 * * *$ & $0.74 * * *$ & $0.70 * * *$ & $0.63 * * *$ & $0.997 * * *$ \\
\hline Germany & $0.58 * * *$ & $0.29 * *$ & $0.50 * * *$ & $0.64 * * *$ & $1.09 * * *$ \\
\hline Greece & $0.64 * * *$ & & & $0.58 * *$ & $0.67 * * *$ \\
\hline Ireland & $0.70 * * *$ & $0.56 * *$ & $0.75 * * *$ & $0.66 * * *$ & $0.87 * * *$ \\
\hline Italy & $0.49 * * *$ & 0.29 & $0.42 * * *$ & $0.59 * * *$ & $0.79 * * *$ \\
\hline Luxembourg & $0.48 * * *$ & & & $0.22 * *$ & $0.91 * * *$ \\
\hline Portugal & $0.48 * * *$ & & & $0.42 * * *$ & $0.55^{* * *}$ \\
\hline Spain & $0.84 * * *$ & & & $0.79 * * *$ & $0.85^{* * *}$ \\
\hline Netherlands & $0.98 * * *$ & $0.57 * * *$ & $0.73 * * *$ & $0.56 * * *$ & $0.93 * * *$ \\
\hline Denmark & $0.49 * * *$ & $0.40 * *$ & $0.48 * * *$ & $0.42 * * *$ & $0.79 * * *$ \\
\hline Sweden & $0.84 * * *$ & & 0.55 & $0.83 * * *$ & $1.29 * * *$ \\
\hline UK & $0.75^{* * *} *$ & $0.88 * * *$ & $0.80 * * *$ & $0.59 * * *$ & $0.73 * * *$ \\
\hline Czech Rep & $0.60 * * *$ & & & $0.79 * *$ & $0.60 * * *$ \\
\hline Hungary & $0.88 * * *$ & & & $1.37 * * *$ & $0.82 * * *$ \\
\hline Poland & $1.14^{* * * *}$ & & & $1.63 * * *$ & $0.91 * * *$ \\
\hline Turkey & $0.85^{* * * *}$ & & & 0.27 & $2.10 * * *$ \\
\hline Norway & $0.90 * * *$ & & $1.00 * * *$ & $0.84 * * *$ & $0.85^{* * * *}$ \\
\hline Switzerland & $0.55^{* * *} *$ & $0.48 * * *$ & $0.59 * * *$ & $0.53 * * *$ & $0.61 * * *$ \\
\hline Average & 0.69 & 0.48 & 0.61 & 0.68 & 0.88 \\
\hline \multicolumn{6}{|c|}{ Panel B: Cash flow beta with respect to US market } \\
\hline Austria & $0.06^{*}$ & 0.00 & $0.12 * *$ & 0.05 & 0.00 \\
\hline Belgium & $0.08 * *$ & $0.16^{* *}$ & 0.10 & 0.07 & -0.01 \\
\hline Finland & 0.07 & & & 0.11 & 0.01 \\
\hline France & $0.14 * * *$ & $0.22 * * *$ & $0.19 * * *$ & $0.13 * *$ & -0.02 \\
\hline Germany & 0.05 & 0.03 & 0.09 & 0.08 & 0.00 \\
\hline Greece & -0.03 & & & -0.09 & 0.07 \\
\hline Ireland & 0.06 & 0.12 & 0.12 & 0.00 & -0.07 \\
\hline Italy & 0.02 & 0.04 & 0.02 & 0.08 & -0.09 \\
\hline Luxembourg & -0.05 & & & 0.02 & -0.13 \\
\hline Portugal & 0.03 & & & 0.11 & -0.06 \\
\hline Spain & $0.12 * *$ & & & 0.12 & 0.01 \\
\hline Netherlands & $0.07 * *$ & $0.17 * * *$ & 0.07 & 0.07 & -0.03 \\
\hline Denmark & 0.00 & 0.02 & -0.03 & 0.04 & 0.00 \\
\hline Sweden & 0.06 & & 0.13 & 0.08 & -0.04 \\
\hline UK & $0.13 * * *$ & $0.25^{* *}$ & 0.11 & $0.08 *$ & 0.07 \\
\hline Czech Rep & 0.11 & & & 0.16 & 0.04 \\
\hline Hungary & $0.13^{*}$ & & & $0.27 *$ & 0.05 \\
\hline
\end{tabular}


Table 4 continued

\begin{tabular}{|c|c|c|c|c|c|}
\hline & Full sample & $1970 \mathrm{~s}$ & $1980 \mathrm{~s}$ & $1990 \mathrm{~s}$ & $2000 \mathrm{~s}$ \\
\hline Poland & 0.12 & & & 0.33 & -0.04 \\
\hline Turkey & -0.09 & & & -0.23 & 0.11 \\
\hline Norway & $0.13^{* *}$ & & $0.19 * *$ & 0.11 & 0.04 \\
\hline Switzerland & $0.08 * *$ & $0.11^{*}$ & $0.12^{*}$ & 0.05 & -0.01 \\
\hline Average & 0.06 & 0.11 & 0.10 & 0.08 & 0.00 \\
\hline \multicolumn{6}{|c|}{ Panel C: Discount rate beta with respect to US market } \\
\hline Austria & $0.19 * * *$ & 0.15 & 0.12 & $0.33^{*}$ & $0.27 *$ \\
\hline Belgium & $0.43^{* * *}$ & $0.33 * *$ & $0.48 * * *$ & $0.38 * * *$ & $0.59 * * *$ \\
\hline Finland & $1.01 * * *$ & & & $0.92 * * *$ & $1.24 * * *$ \\
\hline France & $0.59 * * *$ & $0.52 * * *$ & $0.51 * * *$ & $0.50 * * *$ & $0.99 * * *$ \\
\hline Germany & $0.52 * * *$ & $0.26^{* *}$ & $0.41 * * *$ & $0.56^{* * *}$ & $1.09 * * *$ \\
\hline Greece & $0.67 * * *$ & & & $0.67 * * *$ & $0.60 * *$ \\
\hline Ireland & $0.64 * * *$ & $0.44 * *$ & $0.64 * * *$ & $0.66^{* * *}$ & $0.94 * * *$ \\
\hline Italy & $0.47 * * *$ & 0.25 & $0.40 * *$ & $0.51 * * *$ & $0.88 * * *$ \\
\hline Luxembourg & $0.53 * * *$ & & & $0.20 * *$ & $1.04 * * *$ \\
\hline Portugal & $0.44 * * *$ & & & $0.31 * *$ & $0.61 * * *$ \\
\hline Spain & $0.72 * * *$ & & & $0.67 * * *$ & $0.84 * * *$ \\
\hline Netherlands & $0.61 * * *$ & $0.40 * * *$ & $0.65 * * *$ & $0.49 * * *$ & $0.96 * * *$ \\
\hline Denmark & $0.49 * * *$ & $0.38 * *$ & $0.51 * * *$ & $0.38 * * *$ & $0.79 * * *$ \\
\hline Sweden & $0.78 * * *$ & & 0.41 & $0.75^{* * *}$ & $1.33 * * *$ \\
\hline UK & $0.62 * * *$ & $0.63 * * *$ & $0.68 * * *$ & $0.51 * * *$ & $0.66^{* * * *}$ \\
\hline Czech Rep & $0.49 * * *$ & & & $0.62 * *$ & $0.56^{* *}$ \\
\hline Hungary & $0.74 * * *$ & & & $1.09 * * *$ & $0.77 * * *$ \\
\hline Poland & $1.01 * * *$ & & & $1.30 * * *$ & $0.95 * * *$ \\
\hline Turkey & $0.94 * * *$ & & & 0.50 & $1.98 * * *$ \\
\hline Norway & $0.77 * * *$ & & $0.81 * * *$ & $0.73 * * *$ & $0.82 * * *$ \\
\hline Switzerland & $0.47 * * *$ & $0.37 * * *$ & $0.47 * * *$ & $0.47 * * *$ & $0.62 * * *$ \\
\hline Average & 0.63 & 0.37 & 0.51 & 0.60 & 0.88 \\
\hline
\end{tabular}

$*, * *, * * *$ denotes statistical significance at the $10,5,1 \%$ level

analyzing this because Campbell (1991) documents a shift in variance from cashflow news to discount-rate news after 1952 and CAPM breaks down only in the postwar period. In Table 5, model 2, we report the results for the benchmark case when only postwar data is used. In this case, discount-rate news continues to be more important than cash-flow news, though, surprisingly, there is now less difference between both. Discount-rate betas continue to be more important than cash-flow betas and their evolution in time is similar to the benchmark case. We do find though an increasing trend in the average cash flow beta across EMU countries. Cross-sectional differences are, however, large. While we see substantial increases in Germany, Greece, Luxembourg, and Italy, cash flow betas decrease in the UK, Norway, Sweden, and even (slightly) in France. Moreover, while increases are often large in percentage terms, they are relatively small in absolute terms. 


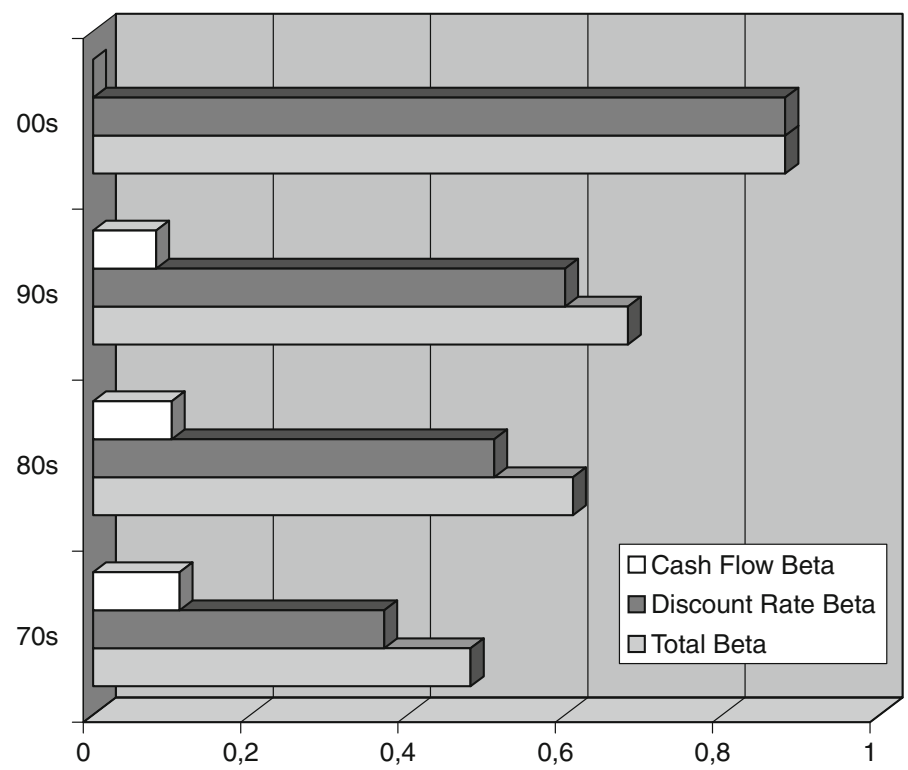

Fig. 1 Average cash flow and discount rate betas over time

\subsubsection{Sensitivity to changes in VAR state variables}

Following Campbell and Vuolteenaho (2004), our benchmark VAR model includes the excess market return, the term spread, the market's smoothed price-earnings ratio, and the small-stock value spread. However, there are other variables that are often used to predict stock returns. In Table 5 we report some of the results obtained in this study when we include other variables in the VAR system. We report the variance of cash-flow news and discount-rate news, their covariance, cash-flow betas, discount-rate betas, and their evolution in time. We report average betas for: (i) the 12 EMU members, (ii) the 3 non-EMU but EU members and, (iii) 3 nonEMU and new EU members.

In the first column, model 1 , where the benchmark case is used, the cash-flow variance is $0.07 \%$ and the discount-rate variance is $0.23 \%$. Therefore, consistent with Campbell and Ammer (1993) and Campbell and Vuolteenaho (2004), discountrate news far exceeds cash-flow news in driving US equity returns. In model 3 , following Chen and Zhao (2009), we replace the price-earnings ratio from the benchmark case by a similar variable that also works as a proxy for expected returns, ${ }^{6}$ the dividend yield. We find that the cash-flow variance is $0.16 \%$ and the discount-rate variance is $0.10 \%$. This is, the trend is reversed. In model 4 , we use the average value spread instead of the small-stock value spread. The results are very similar to those reported for the benchmark model. Following Liu and Zhang (2008), in models 5 and 6, we use the book-to-market spread and market-to-book

\footnotetext{
${ }^{6}$ See Campbell and Shiller (1988a), Campbell and Ammer (1993), Campbell and Mei (1993), and Campbell and Vuolteenaho (2004).
} 
Panel A

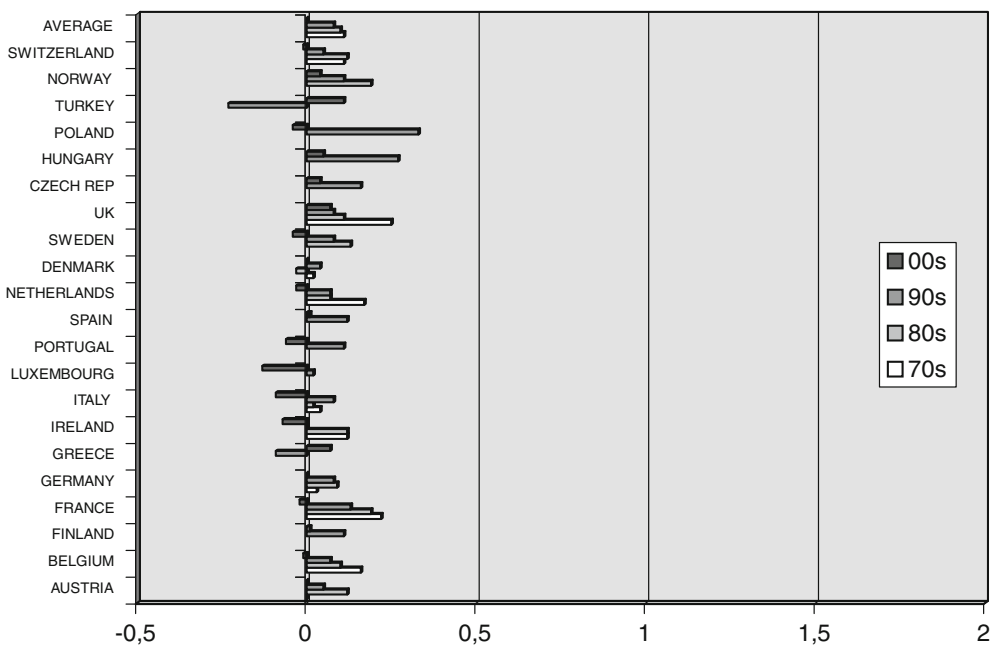

Panel B

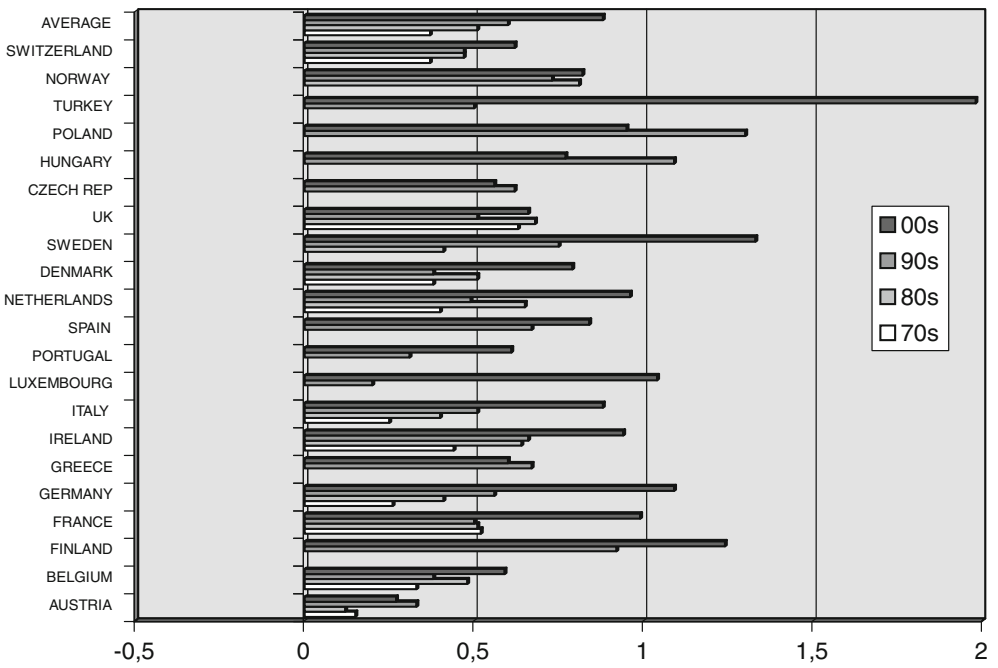

Fig. 2 Cash flow and discount rate betas over time. a Cash flow betas with respect to US market b Discount rate betas with respect to US market

spread instead of the value spread as useful predictors of returns. The results are also similar to the benchmark case. In model 7, we follow Campbell and Vuolteenaho (2004) and add to the benchmark case two variables that are often used to predict stock returns: the dividend yield and the Treasury bill rate. With this combination of variables, results are also very similar to those reported for the benchmark case. Finally, model 8 includes the set of variables from Petkova (2006): the excess market return, the term spread, the dividend yield, the default spread (Baa yield over 
Table 5 Robustness checks

\begin{tabular}{|c|c|c|c|c|c|c|c|c|c|}
\hline & \multicolumn{9}{|l|}{ Models } \\
\hline & & 1 & 2 & 3 & 4 & 5 & 6 & 7 & 8 \\
\hline 1929-2005 & & + & & + & + & + & + & + & + \\
\hline 1952-2005 & & & + & & & & & & \\
\hline Excess return & & + & + & + & + & + & + & + & + \\
\hline Term spread & & + & + & + & + & + & + & + & + \\
\hline PE ratio & & + & + & & + & + & + & + & \\
\hline $\begin{array}{l}\text { Small-stock value } \\
\text { spread }\end{array}$ & & + & + & + & & & & + & \\
\hline Dividend yield & & & & + & & & & + & + \\
\hline Value spread & & & & & + & & & & \\
\hline $\begin{array}{l}\text { Book-to-market } \\
\text { spread }\end{array}$ & & & & & + & & & & \\
\hline $\begin{array}{l}\text { Market-to-book } \\
\text { spread }\end{array}$ & & & & & & + & & & \\
\hline Default spread & & & & & & & & & + \\
\hline Treasury bill rate & & & & & & & & + & + \\
\hline Variance of $C F$ & & $0.07 \%$ & $0.05 \%$ & $0.16 \%$ & $0.06 \%$ & $0.05 \%$ & $0.05 \%$ & $0.08 \%$ & $0.20 \%$ \\
\hline Variance of $D R$ & & $0.23 \%$ & $0.08 \%$ & $0.10 \%$ & $0.20 \%$ & $0.19 \%$ & $0.19 \%$ & $0.22 \%$ & $0.09 \%$ \\
\hline $\operatorname{Cov}(C F, D R)$ & & $0.00 \%$ & $-0.02 \%$ & $-0.01 \%$ & $-0.02 \%$ & $-0.02 \%$ & $-0.03 \%$ & $0.00 \%$ & $0.00 \%$ \\
\hline \multirow[t]{4}{*}{12 (EMU) } & Beta $C F$ & 0.05 & 0.23 & 0.51 & 0.11 & 0.14 & 0.10 & 0.19 & 0.61 \\
\hline & Beta $D R$ & 0.57 & 0.41 & 0.12 & 0.52 & 0.49 & 0.54 & 0.42 & 0.03 \\
\hline & $\begin{array}{c}\Delta \text { Beta } \\
\quad C F\end{array}$ & $-196 \%$ & $59 \%$ & $100 \%$ & $-19 \%$ & $118 \%$ & $745 \%$ & $132 \%$ & $102 \%$ \\
\hline & $\begin{array}{c}\Delta \text { Beta } \\
D R\end{array}$ & $136 \%$ & $125 \%$ & $105 \%$ & $129 \%$ & $120 \%$ & $127 \%$ & $137 \%$ & $46 \%$ \\
\hline \multirow[t]{4}{*}{$3($ non $\mathrm{EMU}+\mathrm{EU})$} & Beta $C F$ & 0.06 & 0.26 & 0.51 & 0.13 & 0.17 & 0.13 & 0.19 & 0.63 \\
\hline & Beta $D R$ & 0.63 & 0.45 & 0.19 & 0.57 & 0.53 & 0.58 & 0.50 & 0.07 \\
\hline & $\begin{array}{c}\Delta \text { Beta } \\
C F\end{array}$ & $-103 \%$ & $-1 \%$ & $85 \%$ & $-58 \%$ & $-32 \%$ & $-62 \%$ & $331 \%$ & $76 \%$ \\
\hline & $\begin{array}{c}\Delta \text { Beta } \\
D R\end{array}$ & $81 \%$ & $88 \%$ & $-34 \%$ & $86 \%$ & $85 \%$ & $93 \%$ & $54 \%$ & $24 \%$ \\
\hline \multirow[t]{4}{*}{3 (new EU) } & Beta CF & 0.12 & 0.42 & 0.71 & 0.28 & 0.32 & 0.25 & 0.30 & 0.95 \\
\hline & Beta DR & 0.75 & 0.50 & 0.18 & 0.60 & 0.58 & 0.66 & 0.57 & -0.05 \\
\hline & $\begin{array}{c}\Delta \text { Beta } \\
\text { CF }\end{array}$ & $-89 \%$ & $-42 \%$ & $-34 \%$ & $-49 \%$ & $-46 \%$ & $121 \%$ & $-59 \%$ & $-27 \%$ \\
\hline & $\begin{array}{c}\Delta \text { Beta } \\
\text { DR }\end{array}$ & $-22 \%$ & $-27 \%$ & $-33 \%$ & $-24 \%$ & $-26 \%$ & $-38 \%$ & $-25 \%$ & $-1276 \%$ \\
\hline
\end{tabular}

We study news and betas when alternative VAR specifications are used. We report the variances of the cashflow news and discount-rate news, and their covariances for the equity market portfolio. We also report the magnitude and time variation of betas. In order to do so, we report average betas for the: (i) 12 EMU countries, (ii) 3 non-EMU but EU countries and, (iii) 3 new EU countries. The plus signs indicate the state variables and sample period included in the VAR model. Excess return refers to the excess log return on the CRSP valueweight index; Term spread is the term yield spread, measured as the yield difference between 10-year constantmaturity taxable bonds and short-term taxable notes; PE ratio is the log ratio of S\&P 500's price to S\&P 500's 10 -year moving average of earnings; Small-stock value spread is the difference in the log book-to-market ratios of small value and small growth stocks; Dividend yield is the dividend-price ratio of the market portfolio; Value spread is the difference in the log book-to-market ratios of value and growth stocks; Book-to-market spread and Market-to-book spread are calculated following Liu and Zhang (2008); Default spread is Baa yield over Aaa yield; Treasury bill rate is the 1-month Treasury bill yield 
Aaa yield), and the Treasury bill rate. As it happened in model 3, replacing the price-earnings ratio by the dividend yield, will make the cash-flow news more important.

If we focus on betas and we exclude models 3 and 8 from our analysis, all models seem to point out that discount-rate betas are higher than cash-flow betas. This result is also robust across countries. Moreover, both betas are higher for less EUintegrated countries. For instance, the 3 new EU members have always higher betas than the 12 EMU members. If we focus on the evolution of betas in time, discountrate betas have increased both in the 12 EMU members and in the 3 non-EMU but EU members. However, they have decreased in the 3 new EU member states. These results are robust across models. Regarding cash-flow betas, there is a general decreasing trend across models if we look at the 3 non-EMU but EU members and the 3 new EU members, but there is not homogeneity in results across models if we look at the 12 EMU members (some models account for a decrease in cash-flow betas and some of them for an increase in betas).

The results are robust to adding many other known return predictors to the VAR system as long as the price-earnings ratio is included in the system. Therefore, it should be noted that our results depend critically on the inclusion of the priceearnings ratio in our aggregate VAR system. If we exclude the price-earnings ratio from the system (models 3 and 8) we no longer find that discount-rate betas are higher than cash-flow betas. As Campbell and Vuolteenaho (2004) and Chen and Zhao (2009) point out, the importance of any state variable depends on the coefficient in the VAR estimation and its persistence. In our benchmark case, the price-earnings ratio is the dominant factor due to its persistence. Campbell and Vuolteenaho (2004) contains a detailed discussion of various reasons why this variable should predict stock returns and should, therefore, be included in the VAR. In fact, the benchmark case gives the best predictive power (adjusted $R^{2}$ at $2.10 \%$ ), if we compare it with those of models 3 (adjusted $R^{2}$ at 1.67\%) and 8 (adjusted $R^{2}$ at $1.14 \%)$.

Finally, the results are also robust to estimating the VAR using real (instead of excess) market returns.

\section{Conclusions}

This paper investigates to what extent the increase in global market betas is mostly due to a convergence of cash flows, of discount rates, or both. We interpret the first as being the result of economic integration, the second as a consequence of financial integration.

We use the framework of Campbell and Shiller (1988a) and Campbell (1991) to decompose the return on the US equity market-our proxy for global news-into its cash-flow and discount-rate news components. Next, following Campbell and Vuolteenaho (2004), we decompose the total beta of a country with respect to the US into a cash-flow and a discount-rate beta. This paper is - to our knowledge- the first to decompose country betas in these two components. 
We show that increasing global market betas is nearly fully the result of an increase in discount-rate betas. Therefore, we conclude that the increase in total market betas is mainly the result of increased financial integration. Finally, we show that this result is robust to alternative ways of calculating cash-flow and discountrate news.

This paper suggests a number of paths for future research. First, it would be interesting to also decompose the beta with respect to the European equity market into its cash-flow and discount-rate components. Given the substantial degree of economic integration within Europe, one would expect that the cash-flow beta would be a more important contributor to the rising equity market beta. Such an analysis requires, however, a correct identification of cash-flow and discount-rate news for the aggregate European market. A second task for future research is to develop such a model. The Campbell-Shiller framework is less suitable in this case, because it does not account for time-varying integration and potential regime changes and structural breaks. The approach recently developed by van Binsbergen and Koijen (2010) looks like a more promising starting point, as it does not rely on instruments to identify cash-flow and discount-rate shocks, and it is more easily adaptable to account for structural changes.

Acknowledgments The authors greatly benefited from discussions with Pilar Abad, Geert Bekaert, Francisco Climent, Esther Eiling, Gerhard Illing, Koen Inghelbrecht, Ralph Koijen, Rafael Santamaria, and Rudi Vander Vennet, as well as seminar participants at the DIW in Berlin, the European Commission in Brussels, the University of Valencia, the University of the Balearic Islands, and the XV Foro de Finanzas in Palma de Mallorca. They also thank two anonymous referees for very helpful comments. Financial support from the European Commission: DG Research in cooperation with DG ECFIN and DG ESTAT (Contract No. SCS8-CT-2004-502642); ERDF and Spanish Ministry of Education and Science (Contract No. ECO2009-14457-C04-04); Generalitat Valenciana (Contract No. GV/2007/082); and Catedra Finanzas Internacionales-Banco Santander is gratefully acknowledged.

Open Access This article is distributed under the terms of the Creative Commons Attribution Noncommercial License which permits any noncommercial use, distribution, and reproduction in any medium, provided the original author(s) and source are credited.

\section{References}

Ahrens, R. (2002). Predicting recessions with interest rate spreads: A multicountry regime-switching analysis. Journal of International Money and Finance, 21, 519-537.

Ammer, J., \& Mei, J. P. (1996). Measuring international economic linkages with stock market data. Journal of Finance, 51, 1743-1763.

Baele, L. (2005). Volatility spillover effects in European equity markets. Journal of Financial and Quantitative Analysis, 40, 373-402.

Baele, L., \& Inghelbrecht, K. (2009). Time-varying Integration and International diversification strategies. Journal of Empirical Finance, 16(3), 368-387.

Baele, L., Ferrando, A., Hordahl, P., Krylova, E., \& Monnet, C. (2004). Measuring European financial integration. Oxford Review of Economic Policy, 20, 509-530.

Bekaert, G., \& Harvey, C. R. (2000). Foreign speculators and emerging equity markets. Journal of Finance, 55, 565-613.

Bekaert, G., Hodrick, R. J., \& Zhang, X. (2009). International stock return comovements. Journal of Finance, 64, 2591-2626. 
Bernard, H., \& Gerlach, S. (1998). Does the term structure predict recessions? The international evidence. International Journal of Finance and Economics, 3, 195-215.

Brennan, M. J., Wang, A. W., \& Xia, Y. H. (2004). Estimation and test of a simple model of intertemporal capital asset pricing. Journal of Finance, 59, 1743-1775.

Campbell, J. Y. (1987). Stock returns and the term structure. Journal of Financial Economics, 18, 373399.

Campbell, J. Y. (1991). A variance decomposition for stock returns. Economic Journal, 101, 157-179.

Campbell, J. Y., \& Ammer, J. (1993). What moves the stock and bond markets? A variance decomposition for long-term asset returns. Journal of Finance, 48, 3-37.

Campbell, J. Y., \& Mei, J. P. (1993). Where do betas come from-asset price dynamics and the sources of systematic-risk. Review of Financial Studies, 6, 567-592.

Campbell, J. Y., \& Shiller, R. J. (1988a). The dividend-price ratio and expectations of future dividends and discount factors. Review of Financial Studies, 1, 195-228.

Campbell, J. Y., \& Shiller, R. J. (1988b). Stock-prices, earnings, and expected dividends. Journal of Finance, 43, 661-676.

Campbell, J. Y., \& Vuolteenaho, T. (2004). Bad beta, good beta. American Economic Review, 94, 12491275.

Campbell, J. Y., \& Yogo, M. (2006). Efficient tests of stock returns predictability. Journal of Financial Economics, 81, 27-60.

Chen, L., \& Zhao, X. (2009). Return decomposition. Review of Financial Studies, 22, 5213-5249.

Eleswarapu, V. R., \& Reinganum, M. R. (2004). The predictability of aggregate stock market returns: Evidence based on glamour stocks. Journal of Business, 77, 275-294.

Engsted, T., \& Tanggaard, C. (2004). The comovement of US and UK stock markets. European Financial Management, 10, 593-607.

Estrella, A., \& Hardouvelis, G. A. (1991). The term structure as a predictor of real economic activity. Journal of Finance, 46, 555-576.

Estrella, A., \& Mishkin, F. S. (1997). The predictive power of the term structure of interest rates in Europe and the United States: Implications for the European Central Bank. European Economic Review, 41, 1375-1401.

Estrella, A., \& Mishkin, F. S. (1998). Predicting US recessions: Financial variables as leading indicators. Review of Economics and Statistics, 80, 45-61.

Fama, E. F., \& French, K. R. (1988). Dividend yields and expected stock returns. Journal of Financial Economics, 22, 3-25.

Fama, E. F., \& French, K. R. (1989). Business conditions and expected returns on stocks and bonds. Journal of Financial Economics, 25, 23-49.

Forbes, K. J., \& Rigobon, R. (2002). No contagion, only interdependence: Measuring stock market comovements. Journal of Finance, 57, 2223-2261.

Hecht, P., \& Vuolteenaho, T. (2006). Explaining returns with cash-flow proxies. Review of Financial Studies, 19, 159-194.

Liu, N., \& Zhang, L. (2008). Is the value spread a useful predictor of stock returns? Journal of Financial Markets, 11, 199-227.

Longin, F., \& Solnik, B. (1995). Is the correlation in international equity returns constant: 1960-1990? Journal of International Money and Finance, 14, 3-26.

Petkova, R. (2006). Do the Fama-French factors proxy for innovations in predictive variables? Journal of Finance, 61, 581-612.

Phylaktis, K., \& Ravazzolo, F. (2002). Measuring financial and economic integration with equity prices in emerging markets. Journal of International Money and Finance, 21, 879-903.

Shiller, R. J. (2000). Irrational exuberance. Princeton: Princeton University Press.

van Binsbergen, J. H., \& Koijen, R. S. J. (2010). Predictive regressions: A present-value approach. Journal of Finance. 